\title{
Pelatihan Skrining Kasus TB Bagi Kader di Desa Babakan Ciparay Kabupaten Bandung
}

\author{
Herwinda Sinaga, Widawati, Linda Hotmaida, Fahmi Fuadah, Lidya Maryani, \\ Gurdani Yogisutanti \\ Sekolah Tinggi Ilmu Kesehatan Immanuel Bandung \\ Penulis korespondensi : gurdani@yahoo.com
}

\begin{abstract}
Abstrak: Kasus Tuberculosis (TB) di Indonesia terdeteksi terjadi peningkatan dalam beberapa tahun terakhir. Keterlibatan masyarakat dalam menanggulangi penyakit TB sangat diperlukan. Kader kesehatan sebagai perwakilan dari masyarakat di tingkat yang paling rendah. Kader di Desa Babakan Ciparay Kabupaten Bandung merupakan salah satu wilayah yang terdapat kasus TB, akan tetapi kader kesehatan di wilayah tersebut belum pernah mendapatkan pelatihan berkaitan dengan penyakit TB. Kegiatan pengabdian masyarakat bertujuan untuk meningkatkan pengetahuan kader tentang TB dan peningkatan keterampilan kader dalam penemuan suspek TB. Pelatihan diikuti oleh kader posyandu di Desa Babakan yang terdiri dari $19 \mathrm{RW}$, masing-masing diwakili 2 orang (38 kader). Pelatihan dilaksanakan selama 2 hari terdiri dari pengetahuan tentang penyakit TB, Komunikasi, Informasi dan Edukasi (KIE) serta praktik penemuan kasus TB, cara pengambilan dahak dan simulasi KIE. Peserta yang hadir pada hari pertama sebanyak 28 orang, dan hari kedua sebanyak 36 orang, beberapa kader berhalangan hadir. Pelatihan yang telah dilakukan terbukti dapat meningkatkan pengetahuan kader, berdasarkan data pretest dan posttest, terdapat peningkatan skor pengetahuan kader. Keterampilan dalam melakukan pengambilan dahak, penemuan kasus dan KIE menjadi meningkat pula. Saran yang dapat diberikan pada Puskesmas Pakuntadang agar memberikan pelatihan serupa pada kader kesehatan di wilayah kerjanya untuk meningkatkan cakupan penemuan kasus/suspek TB.
\end{abstract}

Kata kunci: kader, kasus, pelatihan, pengetahuan, suspek TB.

Abstract: Tuberculosis cases in Indonesia have detected an increase in recent years. Community involvement in tackling TB is urgently needed. Health cadres as representatives from the community at the lowest level. Cadres in Babakan Village Ciparay, Bandung Regency are one of the areas that have $T B$ cases, but health cadres in the region have never received training related to $T B$ disease. Community service activities aim to increase cadre knowledge about TB and increase cadre skills in finding suspected TB. The training was attended by posyandu cadres in Babakan Village consisting of 19 RWs, each represented by 2 people (38 cadres). The training was held for 2 days consisting of knowledge about TB, Communication, Information and Education (IEC) as well as the practice of TB case finding, how to collect phlegm and IEC simulation. Participants who attended on the first day were 28 people, and the second day as many as 36 people, some cadres were unable to attend. The training that was carried out was proven to be able to increase cadre knowledge, based on pretest and posttest data, there was an increase in cadre knowledge score. Skills in making expectoration, case finding and IEC increase as well. Suggestions can be given to Pakuntadang Community Health Center to provide similar training to health cadres in their working area to increase the coverage of TB case / suspect findings.

Keywords: cadre, case, knowledge, training, TB suspected.

Volume 1, Nomor 1, Maret 2020 | 1

Pelatihan Skrining Kasus TB Bagi Kader di Desa Babakan Ciparay Kabupaten Bandung

Herwinda Sinaga, Widawati, Linda Hotmaida, Fahmi Fuadah, Lidya Maryani, Gurdani Yogisutanti https://doi.org/10.26874/jakw.v1i1.9 


\section{Pendahuluan}

Sekitar sepertiga penduduk dunia telah terinfeksi oleh Mycobacterium tuberkulosis. Diperkirakan 95\% kasus TB dan 98\% kematian akibat TB di dunia, terjadi pada negaranegara berkembang. Diperkirakan seorang pasien TB dewasa, akan kehilangan rata-rata waktu kerjanya 3 sampai 4 bulan. Hal tersebut berakibat pada kehilangan pendapatan tahunan rumah tangganya sekitar 20-30\%. Jika ia meninggal akibat TB, maka akan kehilangan pendapatannya sekitar 15 tahun. Selain merugikan secara ekonomis, TB juga memberikan dampak buruk lainnya secara sosial stigma bahkan dikucilkan oleh masyarakat (Putri dan Hisyam, 2014).

Dalam RPJMN 2015-2019, Indonesia tetap memakai prevalensi TB, yaitu 272 per 100.000 penduduk secara absolut (680.000 penderita) dan hasil survey prevalensi TB 20132014 yang bertujuan untuk menghitung prevalensi TB paru dengan konfirmasi bakteriologis pada populasi yang berusia 15 tahun ke atas di Indonesia menghasilkan: 1). Prevalensi TB paru smear positif per 100.000 penduduk umur 15 tahun ke atas adalah 257 (dengan tingkat kepercayaan 95\% 210-303) 2). Prevalensi TB paru dengan konfirmasi bakteriologis per 100.000 penduduk umur 15 tahun ke atas adalah 759 (dengan interval tingkat kepercayaan 95\% 590 - 961) 3). Prevalensi TB paru dengan konfirmasi bakteriologis pada semua umur per 100.000 penduduk adalah 601 (dengan interval tingkat kepercayaan 95\% 466-758); dan 4). Prevalensi TB semua bentuk untuk semua umur per 100.000 penduduk adalah 660 ( dengan interval tingkat kepercayaan 95\% 523-813), diperkirakan terdapat 1.600 .000 (dengan interval tingkat kepercayaan 1.300.000-2.000.000) orang dengan TB di Indonesia (Rahmawati, 2016).

Pengendalian Penyakit Menular yang termasuk dalam komitmen global dilakukan dengan metode EWARS. Pengembangan Early Warning and Respons System (EWARS) atau Sistem Kewaspadaan Dini dan Respon (SKDR) merupakan penguatan dari Sistem Kewaspadaan Dini terhadap kejadian luar biasa (SKD-KLB). Melalui Penggunaan EWARS ini diharapkan terjadi peningkatan dalam deteksi dini dan respon terhadap peningkatan trend kasus penyakit khususnya yang berpotensi menimbulkan KLB. Analisis pengendalian penyakit TB meliputi: 1) Input, terdiri dari ; SDM (Dokter, Perawat, Petugas TB, Analis, Bidan), Biaya (BOK, DAK, Non fisik, kapitasi), Sarana dan Prasaran habis pakai (TCM, cartride, Mikroskop, Cat ZN, Obyek glass), Obat TBC (paket DOTS, obat MDR), kendaraan outreach/PIS PK (sepeda motor, pusling), 2) Proses terdiri dari; penemuan Kasus Secara 
Aktif, penggunaan teknik diagnosa yang sensitif dan spesifik, gerakan penemuan kasus (pelacakan kontak kelompok masyarakat), pengobatan secara disiplin, public private mix (mencegah under reporting dan misdetection) dan 3) Output terdiri dari: penemuan kasus TBC, semua fasyankes lapor SITT (NTP) dan pakai DOTS, pengobatan TBC sesuai standar (DOTS) (Hapsari dkk., 2017).

Hasil penelitian pada kader kesehatan dalam penemuan kasus tuberculosis BTA positif melalui edukasi dengan pendekatan theory of planned behavior (TPB) bahwa peran kader kesehatan dalam penemuan kasus TB dengan metode edukasi menggunakan theory of planned behavior memiliki hubungan kuat dalam penemuan kasus TB dan memotivasi pasien TB untuk berobat ke pelayanan kesehatan (Sumartini, 2014). Kegiatan pengabdian masyarakat yang dilakukan oleh dosen Universitas Padjadaran Bandung dengan memberikan pelatihan pada kader kesehatan tentang deteksi dini tuberkulosis paru di Desa Jayamukti dan Desa Cigadog Kecamatan Leuwisari Kabupaten Tasikmalaya terbukti bermanfaat bagi kader dalam meningkatkan pengetahuan dan keterampilan kader (Hernawaty dkk, 2014).

Dari hasil pertemuan dengan pihak Puskemas Pakutandang pada tanggal 1 dan 17 September 2019 didapatkan informasi jumlah pasien TB sebanyak 94 orang dan pasien yang mendapatkan pelayanan TB sebanyak 87 orang, serta terdapat sisa 7 orang pasien TB yang belum mendapatkan pelayanan TB. Kasus TB di Indonesia terdeteksi terjadi peningkatan dalam beberapa tahun terakhir. Keterlibatan masyarakat dalam menanggulangi penyakit TB sangat diperlukan dengan melibatkan kader kesehatan sebagai perwakilan dari masyarakat di tingkat yang paling rendah. Desa Babakan Ciparay Kabupaten Bandung merupakan salah satu wilayah yang terdapat kasus TB, akan tetapi kader kesehatan di wilayah tersebut belum pernah mendapatkan pelatihan berkaitan dengan penyakit TB.

Masalah tersebut menjadi salah satu fokus perhatian tenaga kesehatan di Sekolah Tinggi Ilmu Kesehatan Immanuel dan Puskesmas Pakutandang mengenai penyakit TB yang tidak diobat menurut riwayat alamiahnya. Hasil pengamatan di Puskesmas tersebut setelah 5 tahun menunjukkan 50\% meninggal, 25\% sembuh sendiri dengan daya tahan tubuh tinggi dan 25\% menjadi kasus kronis yang tetap menular, sehingga diperlukan metode penjaringan suspek TB melalui pemberian pelayanan KIE (Komunikasi, Edukasi dan Informasi) dengan melibatkan peran kader kesehatan di wilayah tersebut. Untuk menguatkan peran kader kesehatan di Desa Babakan Kecamatan Ciparay Kabupaten Bandung dalam meningkatkan pelayanan kesehatan penderita TB dalam pencapaian indikator standar pelayanan minimal kesehatan, beberapa 
dosen di Sekolah Tinggi Ilmu Kesehatan (STIKes) Immanuel bekerja sama dengan Puskesmas Pakutandang menyelenggarakan pengabdian masyarakat dengan menyelenggarakan skrining TB bagi kader di Desa Babakan Kecamatan Ciparay Kabupaten Bandung.

\section{Metode}

\subsection{Persiapan}

Pelaksanaan kegiatan pengabdian masyarakat diawali dengan melakukan persiapan. Kegiatan pelatihan kader kesehatan dilaksanakan berdasarkan permintaan dari pihak Puskesmas Pakutandang sesuai dengan kebuhan di wilayah kerjanya. Persiapan dimulai dengan mengadakan pertemuan antara dosen STIKes Immanuel Bandung dengan pihak Puskesmas Pakutandang untuk menentukan pembagian tugas dalam pelaksanaan pengabdian masyarakat.

Pembagian tugas meliputi pembagian tim pelatih dan narasumber, serta pembagian pembebanan pembiayaan kegiatan yang akan dilaksanakan. Selain itu, penentuan lokasi, waktu dan jumlah kader yang akan dilatih juga dibicarakan dalam pertemuan awal dengan Puskesmas Pakutandang. Kegiatan administratif surat-menyurat serta pengadaan sertifikat dilakukan oleh STIKes Immanuel Bandung.

\subsection{Pelaksanaan}

Pelatihan Skrining Suspek Kasus TB pada kader kesehatan di Desa Babakan Kecamatan Ciparay Kabupaten Bandung dilaksanakan selama 2 hari, yaitu pada tanggal 7 dan 8 Oktober 2019, bertempat di Balai Desa Babakan, Ciparay. Pemateri dan nara sumber serta fasilitator berasal dari Puskesmas Pakutandang dan dosen STIKes Immanuel Bandung.

Peserta diikuti oleh perwakilan dari 19 RW yang ada di Desa Babakan, masing-masing diwakili oleh 2 orang kader kesehatan. Tujuan pelatihan adalah peningkatan pengetahuan kader tentang penyakit TB, peningkatan kemampuan kader dalam penemuan suspek kasus TB di wilayahnya dan dapat mengambil sampel dahak dan mengirimkannya ke Puskesmas Pakutandang menggunakan peralatan yang telah disediakan. Selain itu adalah kemampuan kader dalam melakukan Komunikasi, Informasi dan Edukasi dalam penemuan suspek kasus TB di masyarakat.

Pelatihan diikuti oleh kader posyandu di Desa Babakan yang terdiri dari 19 RW, masingmasing diwakili 2 orang (38 kader). Pelatihan dilaksanakan selama 2 hari terdiri dari 
pengetahuan tentang penyakit TB, Komunikasi, Informasi dan Edukasi (KIE) serta praktik penemuan kasus TB, cara pengambilan dahak dan simulasi KIE. Peserta yang hadir pada hari pertama sebanyak 28 orang, dan hari kedua sebanyak 36 orang, beberapa kader berhalangan hadir.

Sebelum pelatihan di hari pertama dilakukan pretest untuk mengetahui pengetahuan kader kesehatan sebelum mengikuti pelatihan, sedangkan posttest dilaksankaan pada hari kedua setelah semua materi pelatihan disampaikan kepada peserta. Instrumen yang digunakan adalah kuesioner pengetahuan yang dibuat berdasarkan materi yang disampaikan dalam kegiatan pelatihan selama 2 hari. Gambar 1 dan 2 memperlihatkan suasana pelatihan dan praktik KIE di Aula Balai Desa Babakan, Ciparay.

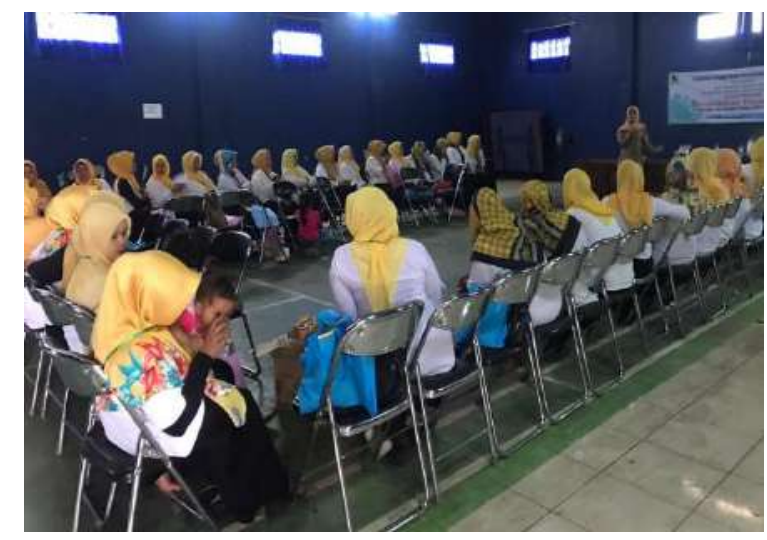

Gambar 1. Suasana Pelatihan Kader Kesehatan pada Pelatihan di Aula Balai Desa Babakan, Ciparay

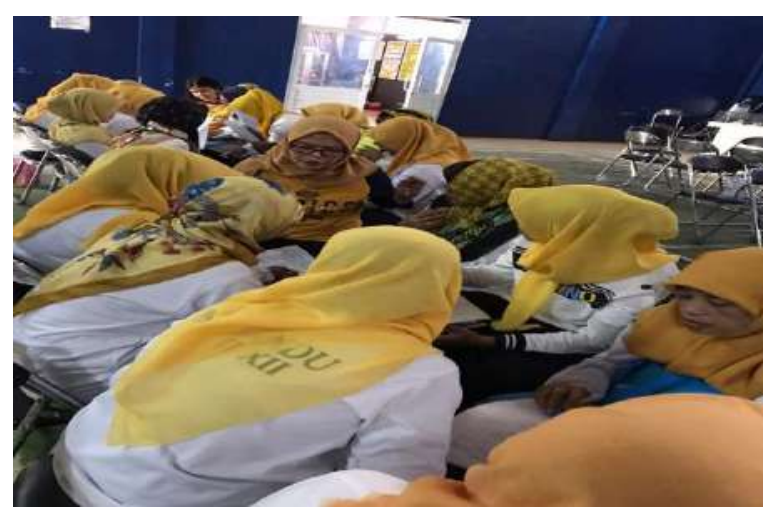

Gambar 2. Peserta berkelompok untuk melakukan praktik KIE

\section{Hasil dan Diskusi}


Kegiatan pelatihan penemuan suspek kasus TB pada kader kesehatan di Desa Babakan Kecamatan Ciparay yang telah dilaksanakan diikuti oleh kader kesehatan yang semuanya berjenis kelamin perempuan. Karakteristik peserta pelatihan ditampilkan pada Tabel 1.

Tabel 1. Karakteristik kader kesehatan peserta pelatihan Skrining Suspek Kasus TB di Desa Babakan Ciparay

\begin{tabular}{|c|c|r|}
\hline Karakteristik & f & \multicolumn{1}{c|}{$\%$} \\
\hline Pendidikan terakhir & & \\
\hline SD & 21 & 58,3 \\
\hline SMP & 10 & 27,8 \\
\hline SMA & 5 & 13,9 \\
\hline Usia (Tahun) & & \\
\hline $30-39$ & 14 & 38,9 \\
\hline $40-49$ & 15 & 41,7 \\
\hline $50-59$ & 6 & 16,7 \\
\hline $60-69$ & 1 & 2,8 \\
\hline Status Perkawinan & & \\
\hline Menikah & 35 & 97,2 \\
\hline Tidak menikah/Janda & 1 & 2,8 \\
\hline Lama menjadi kader (tahun) & & \\
\hline $0-5$ & 32 & 88,9 \\
\hline $6-10$ & 1 & 2,8 \\
\hline $11-15$ & 2 & 5,6 \\
\hline $16-20$ & 1 & 2,8 \\
\hline Jumlah anak (orang) & & \\
\hline $0-2$ & 14 & 38,9 \\
\hline$>2$ & 22 & 61,1 \\
\hline
\end{tabular}

Merujuk kepada Tabel 1, sebagian besar peserta pelatihan berusia antara 30-39 tahun $(38,9 \%)$ dan hanya 1 orang yang berusia di atas 60 tahun $(2,8 \%)$. Sebagian besar berpendidikan tamat Sekolah Dasar (SD) dan tidak ada yang tamat perguruan tinggi. Kader dengan tingkat pendidikan Sekolah Menengah Atas (SMA) atau sederajat hanya 5 orang $(13,9 \%)$ dan 10 orang $(27,8 \%)$ berpendidikan terakhir tamat Sekolah Menengah Pertama (SMP) atau sederajat. Hampir semua kader mempunyai status menikah (97,2\%) dan semuanya adalah ibu rumah tangga. Lama menjadi kader ternyata berkisar antara 0-20 tahun. Sebagian besar telah menjadi kader antara 0-5 tahun $(88,9 \%)$, dan ada 1 orang yang telah menjadi kader selama lebih dari 15 tahun (2,8\%). Seluruh responden adalah ibu rumah tangga yang telah memiliki anak. Sebagian besar kader memiliki anak lebih dari 2 orang yaitu sebanyak 22 orang kader $(61,1 \%)$ dan yang memiliki anak kurang dari 2 sebanyak 14 orang $(38,9 \%)$.

Hasil pretest dan posttest pelatihan skrining suspek kasus TB pada kader dapat dilihat pada grafik yang ditampilkan pada Gambar 3. Berdasarkan grafik tersebut, terdapat 
peningkatan pengetahuan kader sebelum dan setelah mengikuti pelatihan skrining suspek TB yang diselenggarakan oleh STIKes Immanuel Bandung bekerja sama dengan Puskesmas Pakutandang Ciparay Kabupaten Bandung.

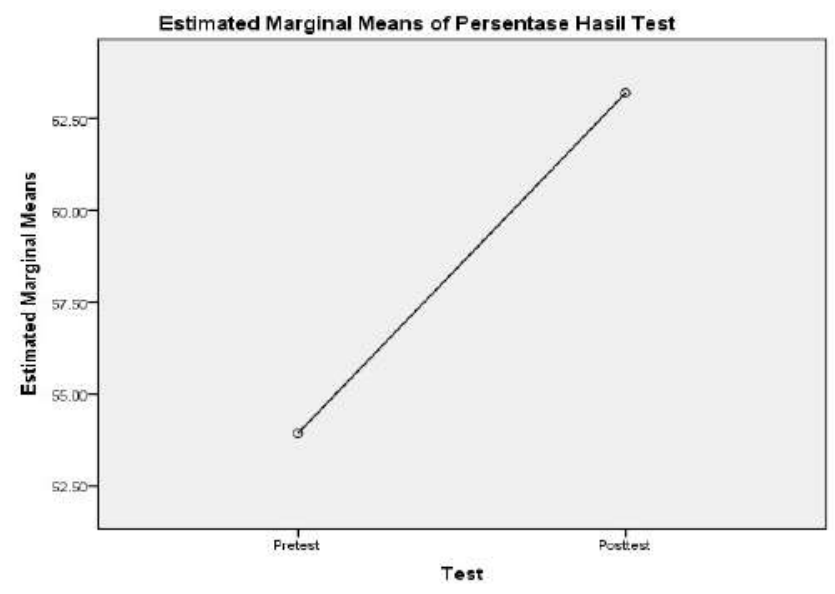

Gambar 3. Hasil pretest dan posttest pengetahuan peserta pelatihan

Pengetahuan kader sebelum dan setelah pelatihan diukur menggunakan 16 pertanyaan pengetahuan dengan skor masing-masing 1 apabila menjawab benar. Hasil analisis data diketahui bahwa skor kader sebelum pelatihan dan setelah pelatihan mengalami peningkatan yang signifikan. Nilai rerata skor pengetahuan sebelum pelatihan adalah 8,63 dan setelah pelatihan meningkat menjadi 10,11. Bila dihitung dalam persentase, pengetahuan sebelum pelatihan reratanya adalah $53,94 \%$, dan setelah pelatihan meningkat menjadi $63,19 \%$.

Hasil kegiatan pelatihan skrining suspek TB pada kader kesehatan di Desa Babakan Ciparay menunjukkan tingkat keberhasilan dengan indikasi adanya respon yang positif dari kader dengan menunjukkan peningkatan pengetahuan melalui metode pre dan posttest pada saat pelatihan. Hasil pretest yaitu sebagian besar kader memiliki pengetahuan kurang sebanyak 49\%, hampir sebagian kecil kader memiliki pengatahuan cukup sebanyak $26 \%$, dan tidak seorangpun kader memiliki pengetahuan baik 0\%. Hasil posttest didapatkan bahwa hampir sebagian besar kader yang memiliki pengetahuan kurang sebanyak $28 \%$, pengetahuan cukup sebanyak 38\% dan pengetahuan baik sebanyak 33\%. Dari hasil pretest dan posttest melalui pengukuran uji T-test untuk sampel berpasangan diperoleh nilai signifikansi atau nilai $\mathrm{p}$ sebesar $0,002(\mathrm{p}<0,005)$ artinya terdapat perbedaan yang bermakna antara skor pengetahuan kader kesehatan sebelum dan setelah mengikuti pelatihan terserbut.

Keterampilan kader dalam melakukan komunikasi, informasi dan edukasi semakin 
meningkat dan lebih terarah pada saat demo dan praktik dalam kelompok. Dengan bantuan pedoman wawancara dan kuesioner yang harus diisi, kader kesehatan yang akan melakukan skrining suspek kasus TB di wilayah masing-masing. Hasil pengukuran praktek KIE didapatkan sebagian kader memiliki keterampilan baik sebanyak 41\% dan sebanyak 33\% memiliki keterampilan kurang.

Pengabdian masyarakat yang telah dilakukan oleh dosen di STIKes Immanuel Bandung dengan melaksanakan kegiatan Pelatihan suspek TB bagi kader kesehatan bekerja sama dengan Puskesmas Pakutandang terbukti telah dapat meningkatkan pengetahuan dan keterampilan kader dalam penemuan suspek kasus TB di wilayahnya masing-masing. Kerja sama dengan Puskesmas Pakutandang memberikan kemudahan dan keuntungan bagi STIKes Immanuel dalam menyelenggarakan pelatihan sesuai dengan kebutuhan lokasi pengabdian masyarakat.

Evaluasi pelaksanaan kegiatan pelatihan kader meliputi evaluasi sasaran, yaitu jumlah peserta yang mengikuti pelatihan. Pada hari pertama ada beberapa kader yang tidak hadir karena berhalangan dan ada keperluan lain yang tidak dapat ditinggalkan, akan tetapi pada hari kedua jumlah kader yang hadir sesuai dengan undangan, yaitu sebanyak 38 orang kader kesehatan dari Desa Babakan yang terdiri dari 19 RW. Tujuan pelatihan adalah meningkatkan pengetahuan keterampilkan dari kader yang mengikuti pelatihan, dan berdasarkan hasil pengumpulan data, didapatkan kesimpulan bahwa terdapat peningkatan skor pengetahuan dan keterampilan dari kader secara siginifikan, sebelum dan setelah mengkikuti pelatihan skrining suspek TB yang dilaksanakan. Evaluasi pamateri atau narasumber diketahui bahwa ada keterlibatan dari Kepala Puskesmas Pakutandang beserta staf yang bertugas untuk memberikan materi pelatihan sesuai dengan yang telah direncanakan. Demikian pula pemateri dari Sekolah Tinggi Ilmu Kesehatan Immanuel juga telah memberikan materi sesuai dengan tujuan pelatihan. Fasilitator membantu peserta dalam melakukan praktik KIE, serta keterlibatan mahasiswa dalam pelaksanaan pretest, posttest dan dokumentasi serta pengolahan data yang telah dikumpulkan. Biaya yang dikeluarkan untuk pelaksanaan pelatihan berasal dari Puskesmas Pakutandan dan STIKes Immanuel Bandung.

Acara pelatihan ditutup dengan memberikan penghargaan dan kenang-kenangan bagi kader yang mendapatkan skor pengetahuan tertinggi dan yang aktif dalam kegiatan pelatihan tersebut. Tanggapan dari peserta sangat baik, karena mereka bersedia utnuk melakukan skrining terhadap suspek TB yang ada di wilayahnya dan akan melaporkannya ke pihak 
Puskesmas Pakutndang sebagai wujud tindak lanjut dari kegiatan pelatihan yang telah diikuti.

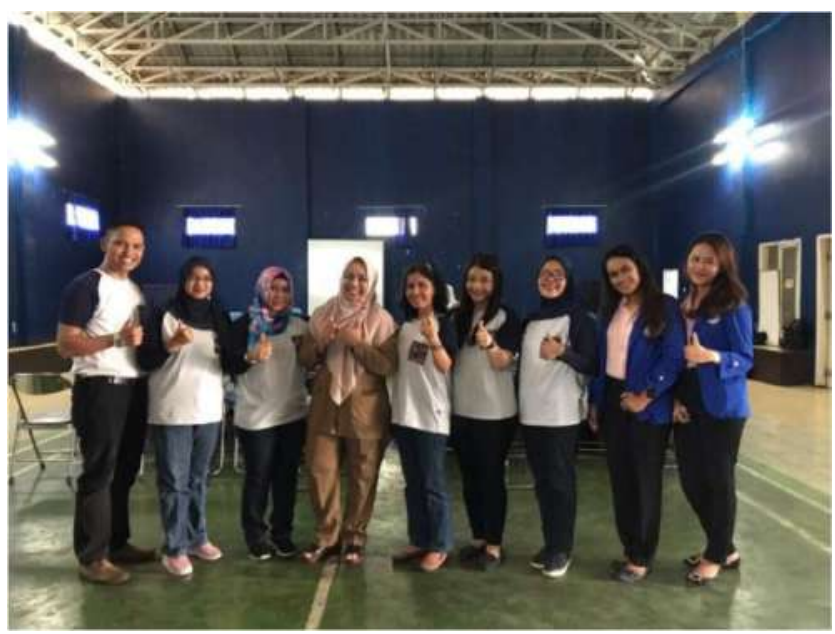

Gambar 4. Tim Dosen STIKes Immanuel Bandung, Mahasiswa dan Kepala Puskesmas Pakutandang Ciparay

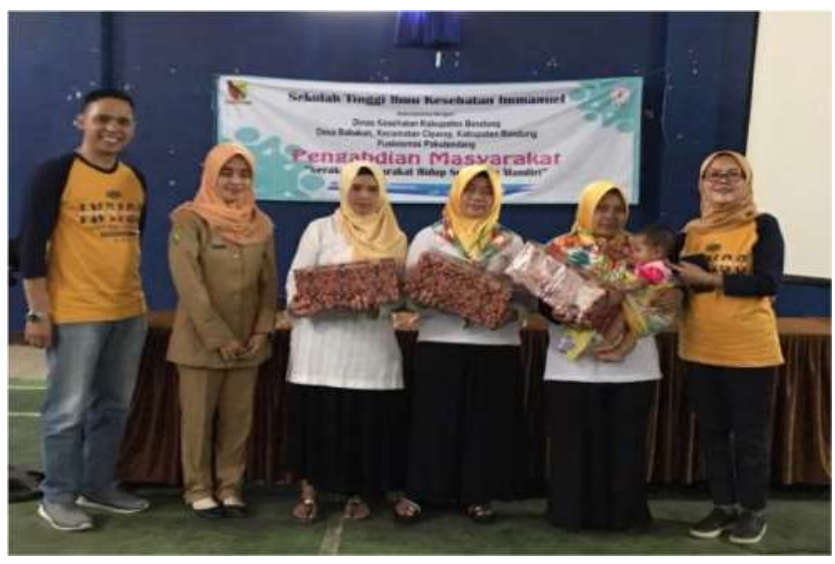

Gambar 5. Pemberian kenang-kenangan pada kader yang mendapatkan skor tertinggi.

Kegiatan pelatihan untuk meningkatkan pengetahuan dan keterampilan kader dalam melaksanakan skrining untuk penderita suspek TB paru di Desa Babakan Kecamatan Ciparay ini sejalan dengan kegiatan pelatihan yang dilakukan di Kota Jayapura, dengan memberikan pelatihan pemrograman dan jaringan computer pada guru dan siswa. Pelatihan yang dilaksanakan terbukti dapat meningkatkan pengetahuan dan keterampilan guru dan siswa (Angriani dan Dayat, 2019).

\section{Kesimpulan}


Kesimpulan dari kegiatan pelatihan skrining suspek TB pada kader kesehatan di Desa Babakan terbukti bermanfaat dan dapat meningkatkan pengetahuan dan keterampilan kader secara signifikan. Saran yang dapat direkomendasikan adalah perlunya pelatihan kader di setiap desa supaya kasus TB yang ada di masyarakat dapat segera ditemukan dan dapat ditangani dengan baik sebelum terjadi penyebaran yang lebih luas. Selain itu, perlu dilakukan follow up pelatihan untuk mengetahui pelaksanaan kegiatan skrining oleh kader yang telah dilatih.

\section{Ucapan Terima Kasih}

Terima kasih kepada STIKes Immanuel Bandung yang telah memberikan dana untuk kegiatan pengabdian masyarakat bagi dosen dan juga terima kasih kepada Kepala Puskesmas Pakutandang beserta staf yang telah memberikan bantuan biaya, tenaga, dan peralatan untuk pelaksanaan pelatihan.

\section{Daftar Referensi}

Angriani, L. dan Dayat, A. R. 2019. PKM Peningkatan kompetensi guru dan siswa melalui pelatihan pemrograman dan jaringan komputer pada sekolah menengah kejuruan di Kota Jayapura. ABDIMAS Jurnal Pebgabdian Masyarakat, 23(2), 92-98.

Hapsari, R. B., Riana, D. A., Purwanto, E., Kandel, N. dan Setiawaty, V. 2017. Early warning alert and response system (EWARS) in Indonesia: Highlight from the first years of implementation, 2009-2011. Health Science Journal of Indonesia, 8(2), 81-87.

Hernawaty, T., Widianti, E. dan Yosep, I. 2014. Upaya peningkatan pelayanan kesehatan masyarakat melalui pelatihan kader kesehatan tentang deteksi dini tuberkulosis paru di Desa Jayamukti dan Desa Cigadog Kecamatan Leuwisari Kabupaten Tasikmalaya. Dharmakarya: Jurnal Aplikasi Ipteks untuk Masyarakat, 3(2), 47-50.

Putri, G. F. S dan Hisyam, B. 2014. Hubungan tingkat kesembuhan tuberkulosis paru dewasa dengan pengobatan metode DOTS dan Non DOTS di Rumah Sakit Haji Abdoel Madjid Batoe Kabupaten Batanghari Provinsi Jambi Tahun 2011. Jurnal Kedokteran dan Kesehatan Indonesia (JKKI), 6(2), 85-94.

Rahmawati, E. N. 2016. Hubungan antara kelengkapan informasi medis dengan keakuratan kode diagnosis tuberkulosis pada domumen rekam medis rawat inap di Rumah Sakit Umum Daerah Dr. Moewardi. Skripsi pada Program Studi Kesehatan Masyarakat Fakultas Ilmu Kesehatan Universitas Muhammadiyah Surakarta, Surakarta.

Sumartini, N. P. 2014. Penguatan peran kader kesehatan dalam penemuan kasus tuberkulosis (TB) BTA positif melalui edukasi dengan pendekatan Theory of Planned Behaviour (TPB). Jurnal Kesehatan Prima, 8(1), 1246-1263. 